\title{
ANALYSIS OF HYGIENE AND SANITATION PRACTICE AMONG HEALTH WORKERS IN THE NUTRITION UNIT, AT MUHAMMADIYAH GAMPING HOSPITAL, YOGYAKARTA
}

\author{
Oldriana Prawiro Hapsari, Iman Permana, Ekorini Listiowati
}

Masters Program in Hospital Management, Universitas Muhammadiyah Yogyakarta

\begin{abstract}
Background: Infection prevention and control is one of key clinical priorities in a hospital to protect patients, visitors and staffs from the risk of healthcareassociated infections caused by bacteria (germs). Food safety in hospitals should be of the utmost importance because their populations are at a higher risk of developing a food-borne illness. This study aimed to analyze the hygiene and sanitation practice among health workers in the nutrition unit, at Muhammadiyah Gamping Hospital, Yogyakarta.

Subjects and Method: This was a qualitative with case study. A sample of 13 food handlers, 1 food service unit supervisor, 1 sanitation unit supervisor, and 1 infection and prevention control unit supervisor, were selected for this study. The dependent variables were knowledge and compliance to food hygiene and sanitation standard procedure. Knowledge was measured by questionnaire. Foodhandler compliance to standard procedure was measured by observation and check-list. Perspective on hygiene and sanitation practice was measured by indepth interview.

Results: Of food-handlers, 10 (77\%) had good knowledge and 3 (23\%) had poor knowledge on hygiene and sanitation. All food handlers were able to demonstrate good practical skills and compliance to food safety, hygiene, and sanitation practice.

Conclusion: All food-handler show good compliance to standard operating procedure of food safety, hygiene, and sanitation practice.

Keywords: hygiene and sanitation, food hygiene, food handling, foodservice, hospital

\section{Correspondence:}

Oldriana Prawiro Hapsari. Masters Program in Hospital Management, Universitas Muhammadiyah Yogyakarta, Jl. Lingkar Selatan, Tamantirto, Kasihan, Bantul, Yogyakarta. Email: clairvoo@gmail.com. Mobile: 082137365836.
\end{abstract}

